\title{
On the Pathogenesis of Regional Cerebral Ischemia in Intracranial Hemorrhage: A Causal Influence of Potassium?
}

\author{
LARS EDVINSSON, HANS C. LOU, AND KIRSTEN TVEDE \\ Department of Clinical Pharmacology, University of Lund, Lund, Sweden [L.E.]; John F. Kennedy Institute, \\ Glostrup, Denmark [H.C.L.]; and Department of Clinical Chemistry, Herlev County Hospital, \\ Herlev, Denmark [K.T.]
}

\begin{abstract}
Cerebral ischemia and intracranial hemorrhage are the most important causes of perinatal brain damage and their pathogenesis seems to be interrelated. Several components in blood have been shown to cause contraction of cerebral blood vessels. In the present study we examined the changes with time of the concentration of standard electrolytes in a mixture of blood and mock cerebrospinal fluid, whether these changes may affect cerebrovascular tone, and if calcium blockers could influence such an effect. Extracellular $\mathrm{K}^{+}$increased to about $23 \mathrm{mM}$ 4 days after mixing when half of the mixture consisted of blood, and remained nearly constant for at least 8 days thereafter. Using isometric recording of circular tension in a controlled tissue bath it was found that isolated human pial arterioles, small arteries, and feline middle cerebral arteries contracted markedly when $\mathrm{K}^{+}$exceeded 10 and 20 $\mathrm{mM}$, respectively. It is concluded that neonatal perihemorrhagic ischemia may be, at least partly, due to leakage of $\mathrm{K}^{+}$from the erythrocytes. The contractile effect of extracellular $\mathrm{K}^{+}$is effectively counteracted by $\mathrm{Ca}^{++}$entry blockers, which therefore may have a role in the prevention of perihemorrhagic ischemia in neonates. (Pediatr Res 20: 478-480, 1986)
\end{abstract}

\section{Abbreviation}

CSF, cerebrospinal fluid

\footnotetext{
Cerebral ischemia and intracranial hemorrhage are the two most important causes of perinatal brain damage. The pathogenesis of the disorders seems to be interrelated, and they often occur together. There is now evidence that focal intracranial hemorrhage may be preceeded by global cerebral ischemia (1). Recent position emission tomography scan studies have shown that intracranial hematomas are surrounded by a large zone of ischemic brain tissue. Such an association is also evident from pathological anatomical studies (2). This close topographical association is intriguing and suggests that hemorrhage may induce ischemia. Similarly, CT studies of patients with subarachnoid hemorrhage have shown a striking association of globular clots or layers of subarachnoid blood and severe vasospasms in adjacent brain tissue, whereas more diffuse hemorrhage failed to produce vasospasms (3). It is apparent that high concentrations

Received June 3, 1985; accepted January 14, 1986.

Correspondence Dr. Hans C. Lou, John F. Kennedy Institute, Gl. Landevej 7, DK-2600 Golstrup, Denmark.

Supported by Grant 5958 from the Swedish Medical Research Council.
}

of blood intracranially may induce vasospasm in adjacent brain tissue.

Several components in blood have been implied in the pathogenesis of perihemorrhagic ischemia. These include oxyhemoglobin (and other constituents of erythrocytes and platelets) as well as circulating neurotransmitters and hormones $(4,5)$. In the present study we have chosen to examine first the changes in standard electrolytes in a mixture of blood and mock CSF, second, whether these changes may affect cerebrovascular tone, and third, if such an effect can be prevented by $\mathrm{Ca}^{++}$blockers. The aim has been to elucidate a possible contributing effect in the development of late ischemia occurring after intracranial hemorrhage.

\section{MATERIALS AND METHODS}

Specimens of the middle cerebral artery were obtained from 15 adult cats of either sex, weighing between 1.8 and $4.5 \mathrm{~kg}$. All animals were killed by bleeding under sodium pentobarbital anesthesia $(30 \mathrm{mg} / \mathrm{kg}$ intraperitoneal), the brain was removed, and the pial vessels were immediately dissected out and placed in aerated Krebs-Ringer buffer solution (for composition, see below). Part of the material was immediately used in the experiments, whereas the rest was used after storage in the buffer solution in a refrigerator $\left(+4^{\circ} \mathrm{C}\right)$ for up to $24 \mathrm{~h}$. Small segments of the middle cerebral artery were used (about $300-400 \mu \mathrm{m}$ wide and 2-4 $\mathrm{mm}$ long).

Human specimens from three individuals were obtained during operations for intracranial tumors. The specimens were immersed into an ice cold Krebs-Ringer solution and transported to the laboratory. Pieces of arterioles (or small arteries) each $200-500 \mu \mathrm{m}$ and 2-4 $\mathrm{mm}$ long were used. The vessels were mounted in a $5 \mathrm{ml}$ temperature controlled tissue bath with a system of L-formed metal holders for recording of isometric circular contractions. The bath contained a solution of the following composition (mM): $\mathrm{NaCl} 119, \mathrm{KCl} 4.6, \mathrm{CaCl}_{2} 1.5, \mathrm{MgCl}_{2}$ 1.2, $\mathrm{NaHCO}_{3} 20, \mathrm{NaH}_{2} \mathrm{PO}_{4} 1.2$, and glucose $11 ; \mathrm{pH}$ 7.4. The bath and the stock solution were maintained at $37^{\circ} \mathrm{C}$ and aerated continuously with a mixture of $95 \% \mathrm{O}_{2}$ and $5 \% \mathrm{CO}_{2}$.

After the arterial preparation had been mounted in the tissue bath, it was subjected to a load of $5 \mathrm{mN}$ and allowed to stabilize at this level. The test drugs were administered after $1.5 \mathrm{~h}$ of equilibration. For further methodological details see Reference 6.

For the $\mathrm{KCl}$-induced contraction the buffer contained: $\mathrm{KCl}$ $127 \mathrm{mM}, \mathrm{NaHCO}_{3} 20 \mathrm{mM}, \mathrm{NaH}_{2} \mathrm{PO}_{4} 1.2 \mathrm{mM}, \mathrm{MgCl}_{2} 1.2 \mathrm{mM}$, $\mathrm{CaCl}_{2} 1.5 \mathrm{mM}$, glucose $11 \mathrm{mM}$; pH 7.4. This buffer was added in different concentrations to the original buffer in order to achieve the $\mathrm{K}^{+}$concentrations seen in Figures 1 and 2 .

The drugs used were diltiazem (Tanabe), verapamil (Hoechst), 

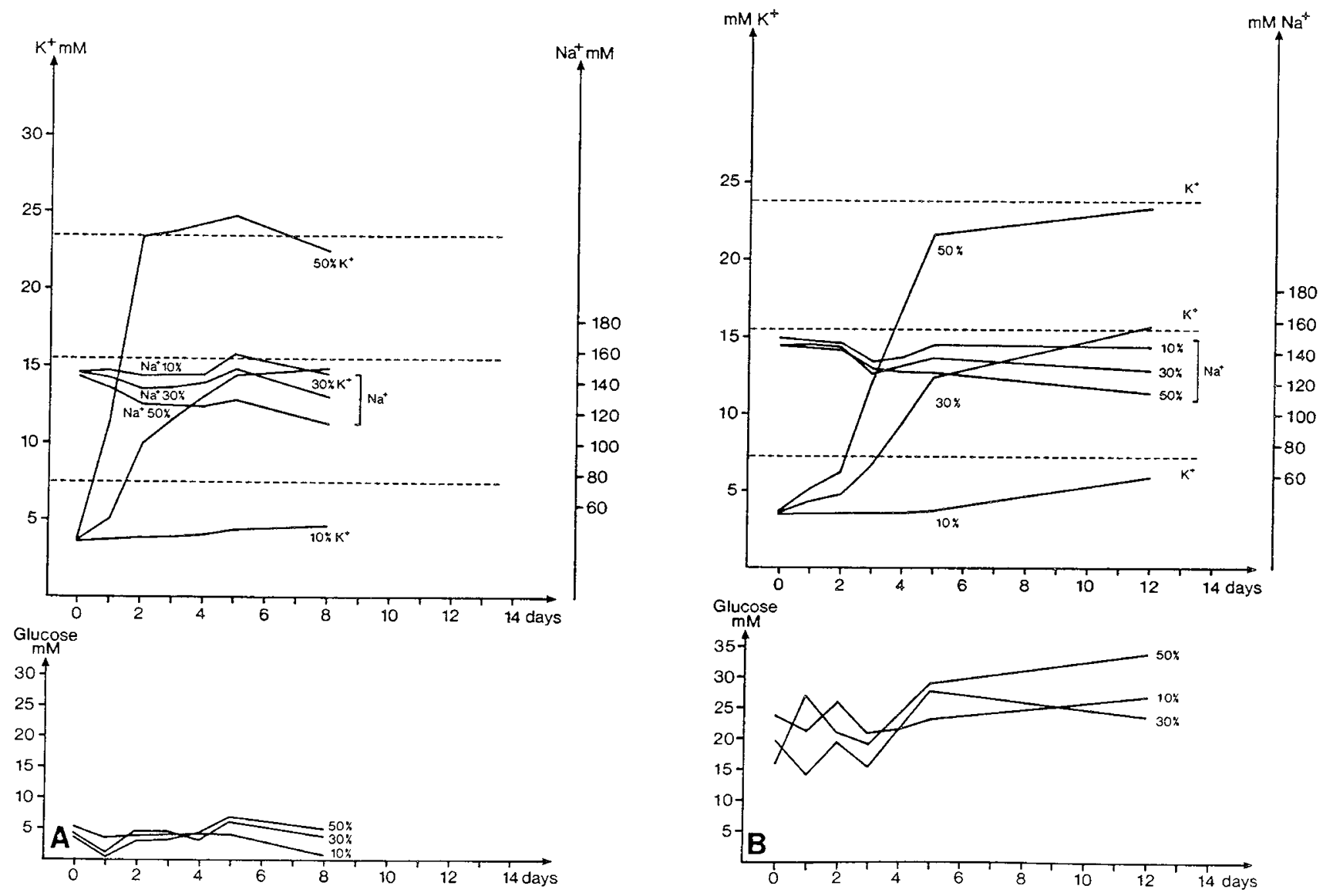

Fig. 1. Increase in extracellular $\mathrm{K}^{+}$concentration over time after mixing of blood with mock CSF containing $A, 5 \mathrm{mM}$ glucose and, $B, 25 \mathrm{mM}$ glucose.

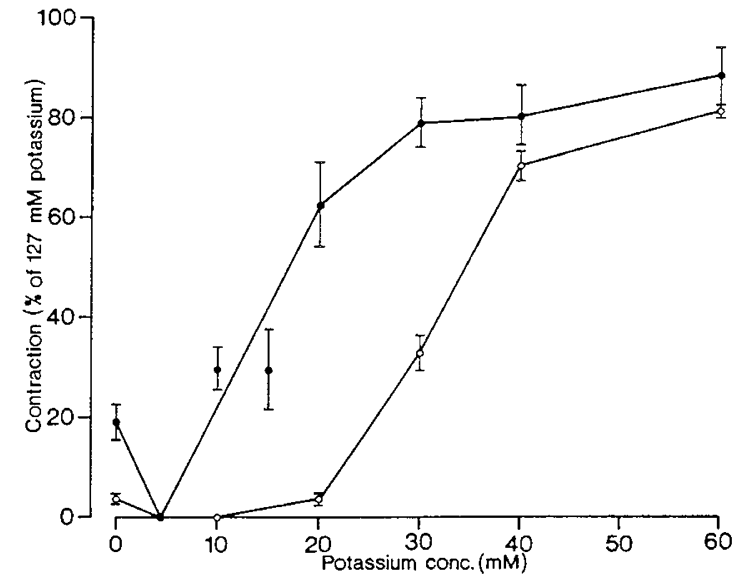

Fig. 2. Contractile effect of $\mathrm{K}^{+}$on isolated feline middle cerebral artery segments and human pial arterioles and small arteries.

nimodipine, and nifedipine (Bayer). The drugs were dissolved according to the manufacturer and dilutions were made with $0.9 \%$ saline.

Influence of blood on electrolytes in artifical CSF. Venous blood (from the experimentators animals) was added to glass tubes containing $10 \mathrm{ml}$ artifical CSF. The composition was (mM) $\mathrm{Na}^{+} 146, \mathrm{~K}^{+} 3, \mathrm{Ca}^{++} 2.3, \mathrm{HCO}_{3}^{-} 25, \mathrm{Cl}^{-} 128.6 ; \mathrm{HPO}_{4}^{-} 1.2, \mathrm{NaPO}_{4}$ $0.1 ; \mathrm{pH} 7.3$. Due to the anaerobic conditions, $\mathrm{pH}$ decreased to about 7.0 in 9 days. Three sets of experiments were made in which glucose concentration was attempted to be kept constant at 5,10 , and $20 \mathrm{mM}$, respectively. In each experiment the amount of blood in the mixture with mock CSF was 10,30, and $50 \%$.
The temperature was kept at $37^{\circ} \mathrm{C}$. After a standardized mixing of CSF and blood (turning the tubes 10 times) $0.5 \mathrm{ml}$ aliquots were drawn from the tubes once daily. These samples were centrifuged at $2000 \times g$ for $10 \mathrm{~min}$ and $0.2 \mathrm{ml}$ of the supernatant or hemolysate was collected for analysis of $\mathrm{Ca}^{+}, \mathrm{K}^{+}$, and $\mathrm{Na}^{+}$(flame photometry).

\section{RESULTS}

Figure 1 shows that extracellular $\mathrm{K}^{+}$increased dramatically during the first days after mixing blood and mock CSF. This increase occurred a little earlier when low glucose concentrations were used $(A)$ compared to high glucose concentrations $(B)$, indicating an acceleration of $\mathrm{K}^{+}$leakage during insufficient energy supply. The leakage of $\mathrm{K}^{+}$was accompanied by hemolysis.

It was strongly dependent on the concentration of blood in the mixture, and was 6- to 7-fold (up until about $24 \mathrm{mM} \mathrm{K}^{+}$) when half of the mixture consisted of blood. After 3-4 days, the extracellular $\mathrm{K}^{+}$remained nearly constant. On the other hand, $\mathrm{Ca}^{++}$and $\mathrm{Na}^{+}$decreased slightly during the experiment.

Figure 2 shows the effect of increasing $\mathrm{K}^{+}$on the isolated middle cerebral artery segment of cat, and isolated pial arterioles or small arteries of man. A marked contraction occurs when the potassium concentration exceeds $20 \mathrm{mM}$ in the feline middle cerebral artery and $10 \mathrm{mM}$ in human pial arterioles and small arteries. The mean concentration causing half maximum contraction for potassium is $35 \mathrm{mM}$ in the feline and $17 \mathrm{mM}$ in the human brain vessels. This corresponds approximately to potassium concentrations obtained already after addition of $30 \%$ mock CSF.

The contractile response to $\mathrm{K}^{+}$was almost completely abolished by the presence of $10^{-6} \mathrm{M}$ nimodipine in the tissue bath, 

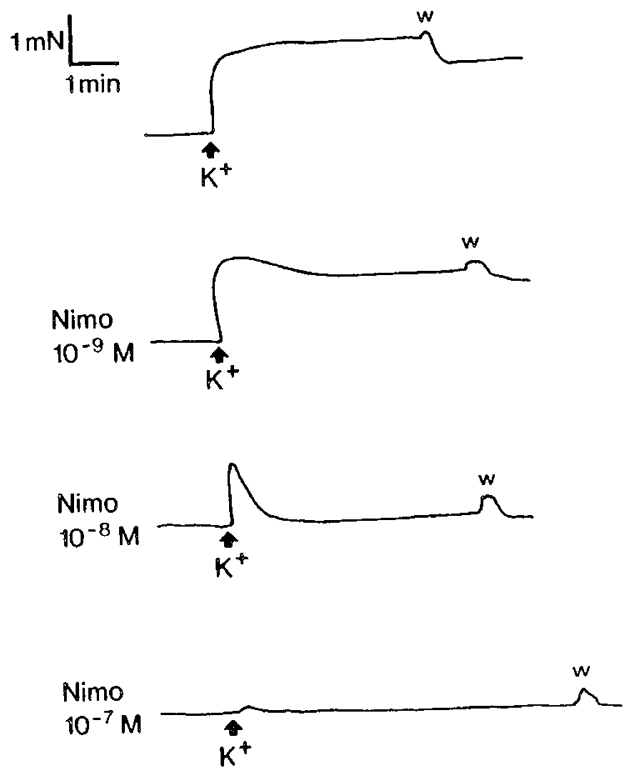

Fig. 3. Inhibitory effect of nimodipine on $\mathrm{K}^{+}(127 \mathrm{mM})$ induced contraction of isolated human cerebral arteriole.

Table 1. Relaxation of isolated feline middle cerebral arteries by four different calcium entry blockers; tone was induced by changing the normal Krebs buffer to a solution containing 127 $m M$ potassium (mean $\pm S E M$ )

\begin{tabular}{lccc}
$\begin{array}{c}\text { Calcium } \\
\text { antagonist }\end{array}$ & $\begin{array}{c}\text { No. of } \\
\text { tests } \\
(n)\end{array}$ & $\begin{array}{c}\text { Mean effective } \\
\text { concentration } \\
\mathrm{IC}_{50} *(\mathrm{M})\end{array}$ & $\begin{array}{c}\text { Maximum } \\
\text { relaxations } \\
\mathrm{I}_{\max } \dagger(\mathrm{mN})\end{array}$ \\
\hline Diltiazem & 7 & $3.2 \times 10^{-7}$ & $6.7 \pm 1.0$ \\
Verapamil & 9 & $6.3 \times 10^{-8}$ & $5.5 \pm 0.5$ \\
Nifedipine & 4 & $1.4 \times 10^{-8}$ & $5.3 \pm 1.1$ \\
Nimodipine & 3 & $1.4 \times 10^{-9}$ & $4.8 \pm 0.9$ \\
\hline
\end{tabular}

* Concentration of drug eliciting half maximum relaxation.

$\dagger$ Maximum relaxation.

with a concentration of drug eliciting half maximum relaxation of $1.4 \times 10^{-9} \mathrm{M}$ for cats (Fig. 3, Table 1) and $2.3 \times 10^{-9} \mathrm{M}$ for man.

The other calcium entry blockers tested showed similar, but less pronounced, effects in the rank order nimodipine $>$ nifedipine $>$ verapamil $>$ diltiazem (Table 1 ). The maximum relaxation obtained for each calcium blockers is given in $\mathrm{mN}$ in Table 1 .

\section{DISCUSSION}

The finding that a high concentration of blood in mock CSF induces large and long lasting increases in the extracellular $\mathrm{K}^{+}$ concentration is important in view of the contractile effect of elevated $\mathrm{K}^{+}$concentrations. This is not to say that such a chain of events has been proven in, for instance, newborns with intracranial hemorrhage. Also the $\mathrm{K}^{+}$concentration in vivo at the site of the hematoma is unknown. $\mathrm{K}^{+}$may be removed at a certain rate in vivo. On the other hand, it is likely that hemolysis occurs at a faster rate in vivo compared to in vitro conditions. But at present no evidence contradicts the concept presented herein that arterial vasospasm is at least partly due to leakage of $\mathrm{K}^{+}$ from erythrocytes. The effect of $\mathrm{K}^{+}$on the vascular smooth muscle cells is probably mediated through depolarization of the cell membrane and opening of potential operated $\mathrm{Ca}^{++}$channels (7). The efficacy of calcium entry blockers to prevent vascular contraction is remarkable and are being evaluated for a possible therapeutic use in adults (8) but to the authors' knowledge no data are available on therapeutical efficacy in newborns. In addition to its cerebrovascular effects high concentrations of extracellular $\mathrm{K}^{+}$also have a dramatic effect on the energy metabolism of the neural tissue itself. Autoradiographic studies with the ${ }^{14} \mathrm{C}$ deoxyglucose method have shown that application of high concentrations of $\mathrm{K}^{+}$results in a large increase in cerebral glucose utilization associated with a spread of transient intense neuronal activity followed by membrane depolarization and electrical depression. Glucose utilization is still increased during recovery (9).

In other words, not only is the potassium leakage likely to induce vasospasm in the surrounding cerebral tissue, but it may also increase the energy needs of that tissue. From this concept it is understandable that intracranial hemorrhage may sometimes lead to cerebral infarction with grave consequences.

\section{REFERENCES}

1. Lou HC, Skov H, Pedersen 1979 Low cerebral blood flow: a risk factor in the neonate. J Pediatr 95:606-609

2. Volpe JJ, Herscovitch P, Perlman JM, Raichle ME 1983 Positron emission tomography in the newborn: extensive impairment of regional cerebral blood flow with intraventricular hemorrhage and hemorrhagic intracerebral involvement. Pediatrics 72:589-601

3. Fisher CM, Kistler JP, Davis JM 1980 Relation of cerebral vasospasm to subarachnoid hemorrhage visualized by computerized tomographic scanning. Neurosurgery 6:1-9

4. Cook DA, Weir BKA, Okawuasaba FK, Krueger CA 1979 Effects of hemoglobin on smooth muscle. Proc West Pharmacol Soc 22:429-434

5. Sasaki T, Asano T, Takakura K, Sano K, Kassell NF 1984 Nature of the vasoactive substance in CSF from patients with subarachnoid hemorrhage. J Neurosurg 60:1186-1191

6. Högestätt ED, Andersson K-E, Edvinsson L 1983 Mechanical properties of rat cerebral arteries as studied by a sensitive device for recording of mechanical activity in isolated small blood vessels. Acta Physiol Scand 117:49-61

7. Högestätt ED, Andersson K-E 1984 Mechanisms behind the biphasic contractile response to potassium depolarization in isolated rat cerebral arteries. J Pharm Exp Ther 228:187-197

8. Towart R, Kazda S 1980 The effect of nimodipine (BAYe9736), a calcium antagonistic dihydropyridine, on cerebral and peripheral vessels. In: Betz $\mathrm{E}$, Grote J, Heuser D, Wullenweber R (eds) Pathophysiology and PharmacoTherapy of Cerebrovascular Disorders. Verlag Gerhard Witzroch, New York, pp 64-67

9. Shinohara M, Dollinger B, Brown G, Rapoport S, Sokoloff L 1979. Cerebral glucose utilization: Local changes during and after recovery from spreading cortical depression. Science 203:188-190 